\title{
Paleoclimatic and provenance implications of magnetic parameters from the Miocene sediments in the Subei Basin
}

\author{
YouSheng Li ${ }^{1,3}$, JiMin Sun 1,2,3*, ZhiLiang Zhang', Bai Su',3, ShengChen Tian ${ }^{1,3}$, and MengMeng Cao ${ }^{1,3}$ \\ ${ }^{1}$ Key Laboratory of Cenozoic Geology and Environment, Institute of Geology and Geophysics, Chinese Academy of Sciences, Beijing 100029, China; \\ ${ }^{2}$ Chinese Academy of Sciences Center for Excellence in Tibetan Plateau Earth Sciences, Chinese Academy of Sciences, Beijing 100101, China; \\ 3University of Chinese Academy of Sciences, Beijing 100049, China \\ Key Points: \\ - Variations of environmental magnetic parameters of the Miocene sediments were established in the Subei Basin \\ - The increased bulk susceptibility, SIRM, ARM, and HIRM were related to tectonic uplift induced provenance change since 13.7 Ma \\ - The parameters of susceptibility ratios, redness and $S$ ratio are climate-dependent, indicating a warmest and humid climate during \\ the middle Miocene Optimum
}

Citation: Li, Y. S., Sun, J. M., Zhang, Z. L., Su, B., Tian, S. C., Cao, M. M. (2020). Paleoclimatic and provenance implications of magnetic parameters from the Miocene sediments in the Subei Basin. Earth Planet. Phys., 4(3), 308-316. http://doi.org/10.26464/epp2020030

\begin{abstract}
Thick sediments from foreland basins usually provide valuable information for understanding the relationships between mountain building, rock denudation, and sediment deposition. In this paper, we report environmental magnetic measurements performed on the Miocene sediments in the Subei Basin, northeastern Tibetan Plateau. Our results show two different patterns. First, the bulk susceptibility and SIRM, ARM, and HIRM mainly reflect the absolute-concentration of magnetic minerals; all have increased remarkably since $13.7 \mathrm{Ma}$, related to provenance change rather than climate change. Second, the ratios of IRM $100 \mathrm{mT} / \mathrm{SIRM}_{\text {, }}$ $\mathrm{IRM}_{100 \mathrm{mT}} / \mathrm{IRM}_{30 \mathrm{mT}}$, and IRM $\mathrm{INOmT}_{10 \mathrm{RM}} / \mathrm{RM}_{60 \mathrm{mT}}$, together with the redness and $S$ ratio, reflect the relative-concentration of hematite, being climate-dependent. Their vertical changes correlate in general with the long-term Miocene climatic records of marine oxygen isotope variations, marked by the existence of higher ratios between 17 and $14 \mathrm{Ma}$. This may imply that global climate change, rather than uplift of the Tibetan Plateau, played a dominant role in the long-term climatic evolution of the Subei area from the early to middle Miocene.
\end{abstract}

Keywords: Environmental magnetism; MMCO; global cooling; the Subei Basin

\section{Introduction}

The Cenozoic Era is characterized primarily by a cooling trend, revealed by comprehensive marine oxygen isotope records (Zachos et al., 2001, 2008). The most significant cooling event occurred at $34 \mathrm{Ma}$ and marked by the formation of the Antarctic Ice Sheet (Zachos et al., 2001). The Mid-Miocene Climatic Optimum (MMCO), with temperatures of $\sim 6{ }^{\circ} \mathrm{C}$ higher than at present, was the warmest period since $34 \mathrm{Ma}$ (Miller et al., 1991; Wright et al., 1992; Flower and Kennett, 1994; Zachos et al., 2001). Furthermore, global cooling after the MMCO, since $14 \mathrm{Ma}$, is believed to have been controlled by the Antarctic cryosphere evolution and/or uplift of the Tibetan Plateau (Molnar et al., 1993; Flower and Kennett, 1994; Miao YF et al., 2012), but which factor played the dominant role is still under debate (Raymo and Ruddiman, 1992; Flower and Kennett, 1994). Understanding regional climate responses to global change and mountain uplift will help address the controversy. In the Tibetan Plateau, sediments in foreland basins offer valuable information on the relationships between mountain up-

Correspondence to: J. M. Sun, jmsun@mail.iggcas.ac.cn

Received 17 DEC 2019; Accepted 21 FEB 2020.

Accepted article online 16 APR 2020.

(C) 2020 by Earth and Planetary Physics. lift, rock denudation and sediment deposition. If we can recover regional climate history, it is possible to examine local responses to tectonic events and global climate change. However, compared to abundant marine records (Flower and Kennett, 1994; Abreu and Haddad, 1998; Flower, 1999; Turco et al., 2001; Zachos et al., 2001; Larsson et al., 2011; Holbourn et al., 2014), long-term terrestrial paleoclimate reconstructions are still limited.

A well preserved fluviolacustrine section was found in the Subei Basin, northeastern Tibetan Plateau, spanning from early to middle Late Miocene (Wang XM et al., 2003; Sun JM et al., 2005). Several researchers have carried out investigations on the area's tectonics (Gilder et al., 2001; Van der Woerd et al., 2001; Wang XM et al., 2003; Ritts et al., 2004; Sun JM et al., 2005; Zhuang GS et al., 2011), paleomagnetism (Gilder et al., 2001; Sun JM et al., 2005) and sedimentary provenance (Ritts et al., 2004; Li JF et al., 2014; Lin X et al., 2015), making it an ideal base for our study. Recently, it was reported that the $\mathrm{MMCO}$ can be identified using pollen records (Sun JM and Zhang ZQ, 2008; Larsson et al., 2011; Miao YF et al., 2011; Hui ZC et al., 2018), geochemical records (Wan SM et al., 2009; Song YG et al., 2018), and magnetic records (Zan JB et al., 2015; Guan C et al., 2019). Compared with investigations of other climatic proxies, studies of environmental magnetism are con- 
venient, nondestructive, and effective in treating loess-paleosol sequences (Heller and Tungsheng, 1984; Verosub et al., 1993; Sun JM and Liu TS, 2000; An ZS et al., 2001; Guo ZT et al., 2002; Deng CL et al., 2005, 2006; Liu QS et al., 2007; Hao QZ et al., 2008) and fluviolacustrine sediments (Jiang HC et al., 2008; Ao H et al., 2010; Song CH et al., 2014; Fang XM et al., 2015; Zhang T et al., 2016; Fu CF et al., 2018; Zan JB et al., 2018), enabling us to reconstruct past climatic changes. Therefore, we performed rock magnetic measurements in the Tiejianggou Section.

The objectives of this study are (1) to reconstruct the climate history from the early to late Miocene in the northeastern Tibetan Plateau, and (2) to examine its relationships with the global climate change and uplift of the Tibetan Plateau.

\section{Geological Setting}

The Subei Basin is located at the junction area of the Altyn Tagh Mountains and the western end of the Danghe Nan Shan (Figure 1). The elevation ranges from 2500 to $3000 \mathrm{~m}$. The Altyn Tagh Fault (ATF) is the first-order feature of the Tibetan Plateau and marks its northern edge (Figure 1); it turns sharply to become a series of thrusts and thus plays a critical role in controlling the development of the thrust-fold belts around the Danghe Nan Shan.

The Subei Basin is cut by three main river channels: Yandantugou, Tiejianggou, and Xishuigou from west to east (Figure 2), respectively. Comparison of magnetostratigraphic results for three sections indicates that the Tiejianggou section holds the most complete set of strata from Oligocene to Miocene (Gilder et al., 2001; Yin A et al., 2002; Sun JM et al., 2005). Thus, our studied section fo- cused on the Tiejianggou section (Figure 2). Magnetostratigraphic results combined with biochronology constrain our sequences from 22.8 to 9.0 Ma (Wang XM et al., 2003; Sun JM et al., 2005). The Tiejianggou Section includes three formations from south to north: the Oligocene Paoniuquan Formation, the Miocene Tiejianggou Formation, and an unnamed formation in late Miocene to Pliocene. The Tiejianggou Formation is limited by two faults (F0 and F1), as its upper and lower boundary, respectively. It is composed of three sedimentary units.

Based on the paleomagnetic results, we calculated the sedimentary rates by using linear interpolations of two neighboring ages (Figure 3). The studied strata can be subdivided into three parts: (1) The lowest unit (22.8-18.8 Ma) mainly contains reddish finegrained mudstones with a thickness of $659 \mathrm{~m}$, representing a shallow lake environment, with a low sedimentary rate of $164.75 \mathrm{~mm} / \mathrm{ka}$; (2) The middle unit $(18.8-13.7 \mathrm{Ma})$ is a mix of brownish mudstones or siltstones and growing interbedded grey sandstones with a thickness of $908 \mathrm{~m}$, implying fluvial and lacustrine environments with a sedimentary rate of $178.04 \mathrm{~mm} / \mathrm{ka}$; (3) the uppermost unit (13.7-9.0 Ma) is predominated by conglomerates and thin siltstone intercalations representing high energy floods with sedimentation rate of $250 \mathrm{~mm} / \mathrm{ka}$ in its lower part, increasing to $450 \mathrm{~mm} / \mathrm{ka}$ after $11 \mathrm{Ma}$.

\section{Material and Methods}

\subsection{Magnetic Experiments}

Two hundred ten samples were obtained, pulverized and then

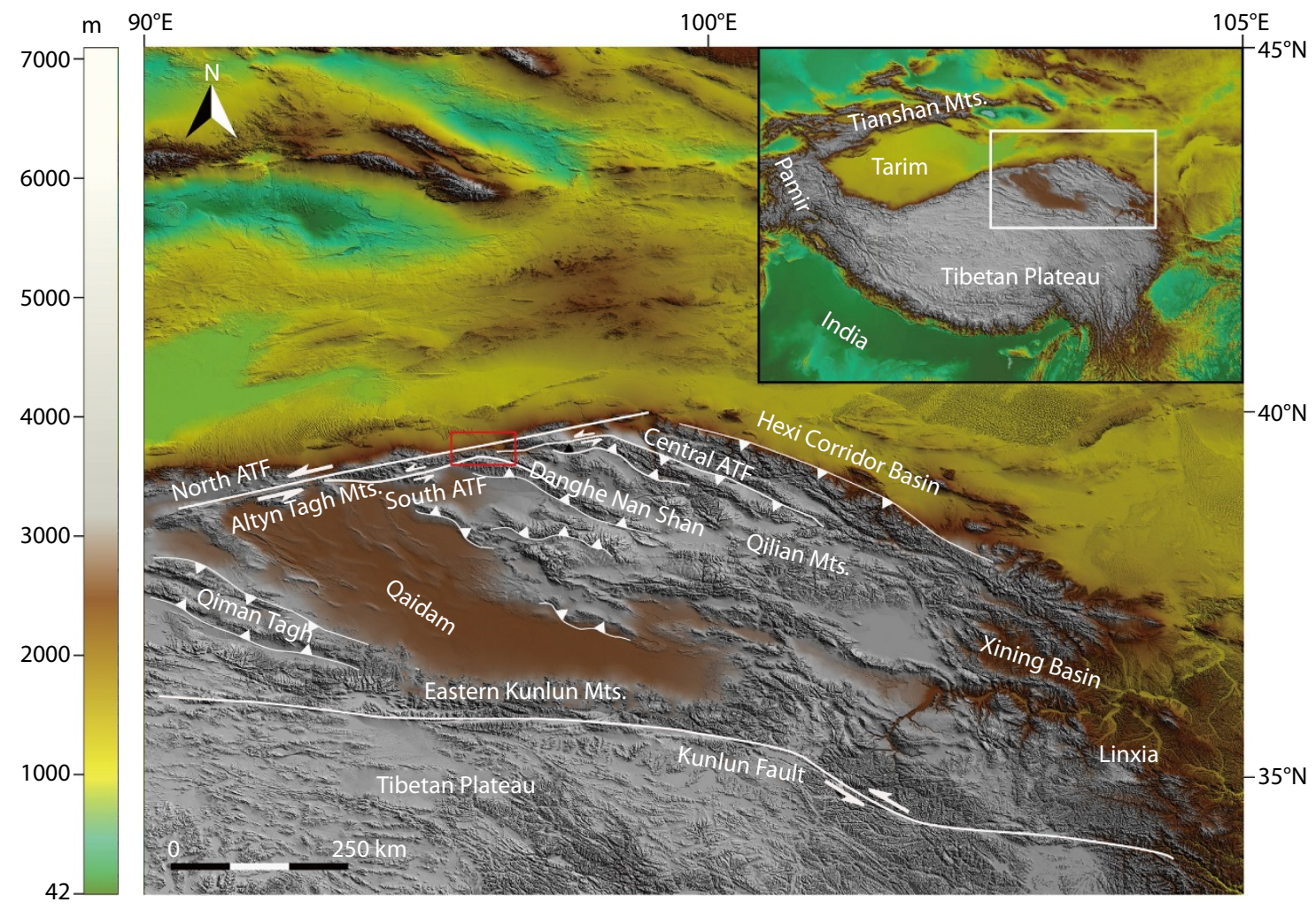

Figure 1. DEM map of the northeastern Tibetan Plateau. Red rectangular defines the Subei area. Tectonic features from Ritts et al. (2004) and Song $\mathrm{CH}$ et al. (2014). 


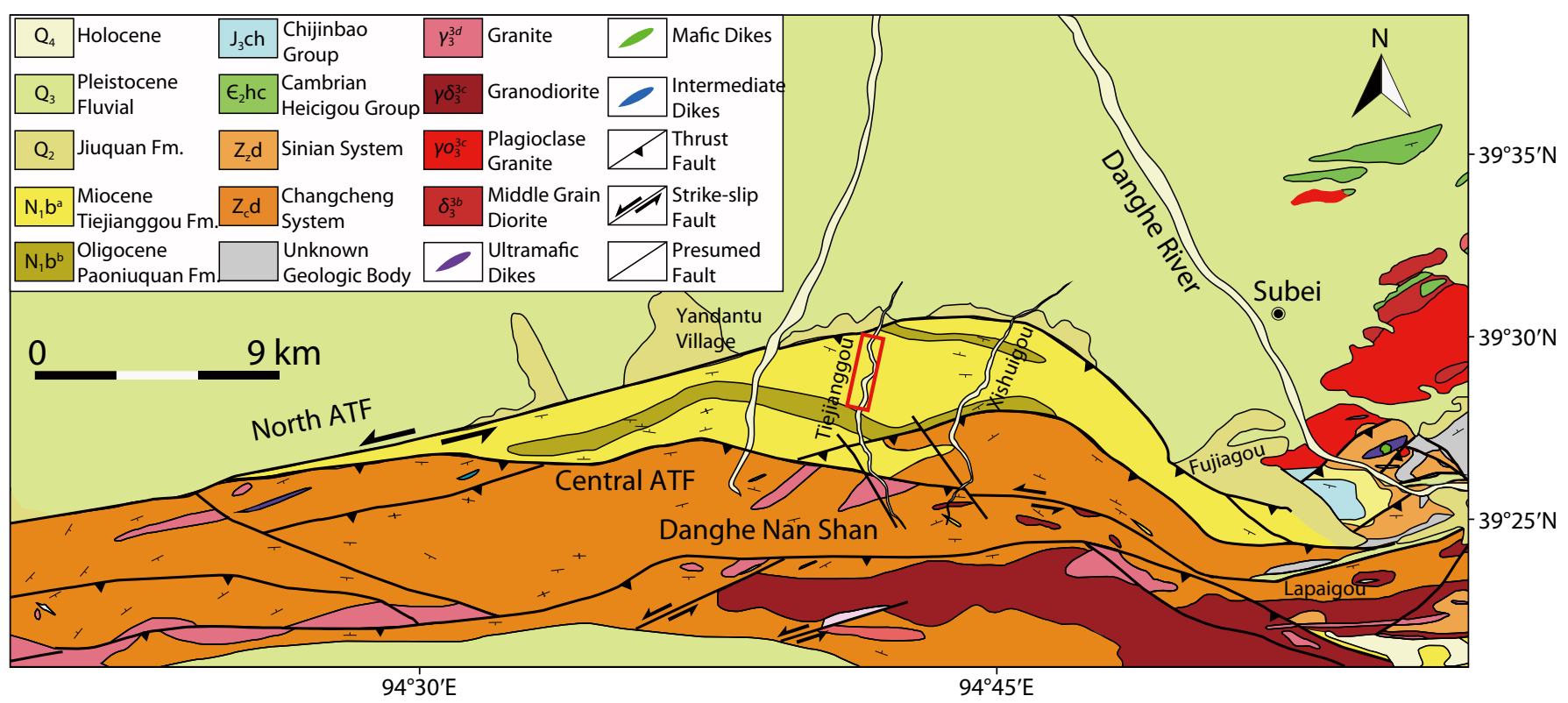

Figure 2. Geologic map of the Subei Area according to the 1:200000 geologic map of Subei (J4605) from National Geological Archive (www.ngac.org.cn). Red rectangular shows the location of the Tiejianggou section in our study.

placed into pre-weighed $2 \mathrm{~cm} \times 2 \mathrm{~cm} \times 2 \mathrm{~cm}$ plastic boxes and weighed. measurements of low-frequency $(976 \mathrm{~Hz})$ and high-frequency $(15616 \mathrm{~Hz})$ magnetic susceptibility were made with a Kappabridge MFK1-FA. Anhysteretic remanent magnetization (ARM) was imparted in a $100 \mathrm{mT}$ peak alternating field with a 0.05 $\mathrm{mT}$ direct current field superimposed, using a 2G-760 model Uchannel superconducting magnetometer. Saturation isothermal remanent magnetization (SIRM) was attained in a $1 \mathrm{~T}$ magnetic field using the $2 \mathrm{G}-660$ Pulse Magnetizer. Followed by three AF demagnetizations of $30 \mathrm{mT}, 60 \mathrm{mT}$, and $100 \mathrm{mT}$, respectively, the corresponding IRM $\mathrm{IR}_{30 \mathrm{mT}}, \mathrm{IRM}_{60 \mathrm{mT}}, \mathrm{IRM}_{100 \mathrm{mT}}$ were produced. After demagnetization, samples were subjected to a $1 \mathrm{~T}$ field and then a $0.3 \mathrm{~T}$ bias field for measurement of IRM $\mathrm{M}_{30 \mathrm{mT}}$. The parameters used in the context were given according to Liu QS et al. (2012):

$$
\begin{gathered}
H I R M=\left(S_{\text {IRM }}+I_{\text {IRM }}-0.3 T\right) / 2, \\
S_{\text {ratio }}=\left(-I R M_{-0.3 T} / \text { SIRM }\right) .
\end{gathered}
$$

\subsection{Color Measurements}

Additionally, we performed color measurements. Samples were first dried at $40{ }^{\circ} \mathrm{C}$ for $24 \mathrm{~h}$ and were then crushed and measured using a Minolta-CM2002 spectrophotometer. For all samples, lightness $\left(L^{*}\right)$, redness $\left(a^{*}\right)$, and yellowness $\left(b^{*}\right)$ were attained. All the above experiments were carried out in the Institute of Geology and Geophysics, Chinese Academy of Sciences.

\section{Results}

\subsection{Magnetic Susceptibility $(\chi)$ and Frequency-Dependent Susceptibility $\left(\chi_{\mathrm{fd}}\right)$}

The values of $X$ range from 1.4 to $13.0 \times 10^{-7} \mathrm{~m}^{3} / \mathrm{kg}$ with an average value of $4.18 \times 10^{-7} \mathrm{~m}^{3} / \mathrm{kg}$. Two stages can be identified in the whole section (Figure 4): Stage A (22.8-13.7 Ma) is characterized by relatively low values $\left(3.53 \times 10^{-7} \mathrm{~m}^{3} / \mathrm{kg}\right.$ in average); Stage $B$
(13.7-9.7 Ma) is marked by relatively high values (average $5.69 \times$ $\left.10^{-7} \mathrm{~m}^{3} / \mathrm{kg}\right)$.

The value of $X_{\mathrm{fd}}$ fluctuates from -0.2 to $0.2 \times 10^{-7} \mathrm{~m}^{3} / \mathrm{kg}$ with an average value of $0.02 \times 10^{-7} \mathrm{~m}^{3} / \mathrm{kg}$.

\subsection{ARM, SIRM, and HIRM}

All three magnetic remanences show a trend similar to that of the magnetic susceptibility (Figure 4). The average values of ARM, SIRM, and HIRM are $2.0 \times 10^{-5} \mathrm{~A} / \mathrm{m}, 6.83 \times 10^{-3} \mathrm{~A} / \mathrm{m}$, and $4.43 \times$ $10^{-3} \mathrm{~A} / \mathrm{m}$, respectively.

\subsection{Interparametric Ratios}

We investigated three interparametric ratios, IRM $100 \mathrm{mT} / \mathrm{IRM}_{30 \mathrm{mT}}$, $I_{1 R M} M_{100 \mathrm{mT}} / \mathrm{IRM}_{60 \mathrm{mT}}$, and IRM I $_{100 \mathrm{mT}} / \mathrm{SIRM}$. They show a similar trend but reveal a different pattern from the bulk magnetic susceptibility and remanent magnetization. We separated the whole section into three stages (Figure 5). Stage I (22.8-17 Ma): the values of these ratios show a gradual increasing trend. Stage II (17-14 Ma): the values reach their maximum and keep steady for the whole period. Stage III (14-9.7 Ma): the value shows a rapidly decreasing trend. Note that in the period at roughly $14 \mathrm{Ma}$, the values of

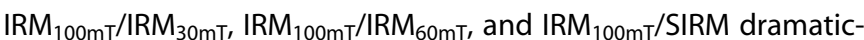
ally drop by $0.35,0.2$, and 0.1 , respectively (Figure 5 ). The value of the $S$ ratio shows a similar trend.

\subsection{Color Records}

We used lightness $L^{*}$, redness $a^{*}$, and yellowness $b^{*}$ of the spherical $L^{*} a^{*} b^{*}$ color space. Color parameters of $a^{*}$ and $L^{*}$ records generally show a trend similar to that of the $S$ ratio (Figure 6). In Stage I (22.8-17 Ma), they show an increasing trend. In Stage II (17-14 $\mathrm{Ma})$, the values remain relatively stable, averaging to $11.1,14.2$, and 60.9, respectively. In Stage III (14-9.7 Ma), the values of redness and lightness decrease from 13.5 to 7.4 and from 67.4 to 52.8 . 


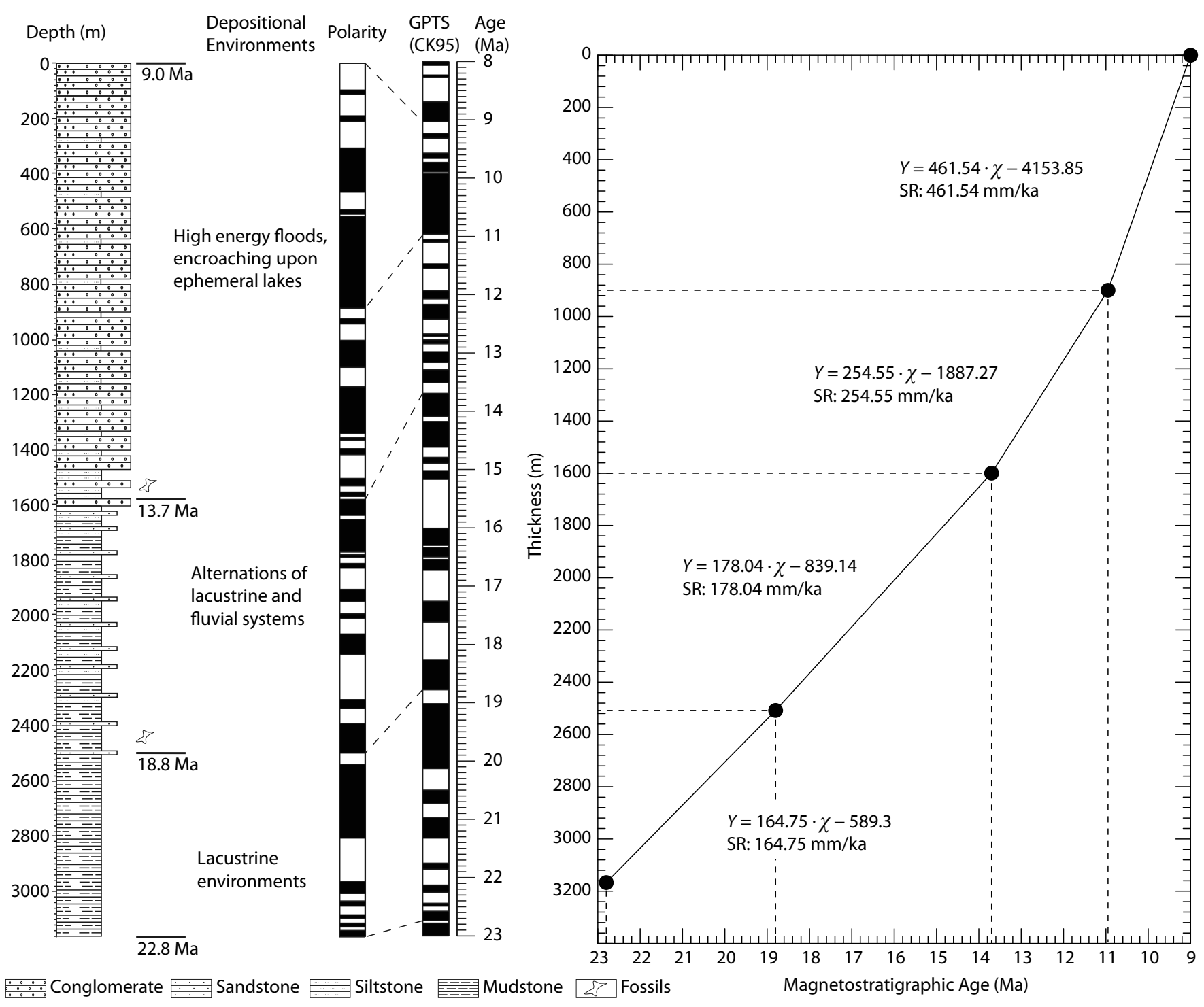

Figure 3. Magnetostratigraphy and sedimentary facies of the studied Tiejianggou Formation according to Sun JM et al. (2005). Corresponding sediments depositional rates are calculated and plotted.

\section{Discussion}

\subsection{Mountain Uplift Since 13.7 Ma}

There is an obvious increase at 13.7 Ma for all four magnetic parameters (Figure 4). Magnetic susceptibility reflects the contributions of all magnetic materials; remanent magnetization refines the picture by reducing the effects of superparamagnetic (SP) particles. ARM is affected by grain size changes and is very sensitive to the concentration of SD particles, while SIRM is responsive to the general magnetic mineral concentration as long as the grain size and mineralogy remain relatively constant. HIRM indicates the mass concentration of high-coercivity minerals, e.g., hematite and goethite. $X_{\mathrm{fd}}$ is used to indicate the presence of SP particles (Zhou LP et al., 1990). The increase at 13.7 Ma implies a higher mass concentration of both ferrimagnetic materials and high-coercivity materials. Both tectonic events and climate change could account for such a change (Zhou LP et al., 1990; Sun JM et al., 2005). Several factors are known or hypothesized to be related to the magnetic properties, including input of aeolian dust, pedogenic processes, low-temperature oxidation, and increased source materials due to active tectonics.

Aeolian dust flux was stable during 22-7 Ma according to Guo ZT et al. (2002). Additionally, the particle size of dust is usually fine, and this is inconsistent with the up-section coarsening trend in our study.

The value of $X_{\mathrm{fd}}$ fluctuates greatly in the lower part of the section; its value is higher after $13.7 \mathrm{Ma}$. It could be logically speculated that the presence of diamagnetic materials such as quartz and plagioclase could account for the lower and fluctuating values before $13.7 \mathrm{Ma}$. Moreover, the value of $\mathrm{Xfd}_{\mathrm{fd}} \%$ is generally less than 0.01 . Therefore, we believe that the contribution of pedogenic processes can be neglected.

According to Ritts et al. (2004), the major paleocurrent in the Subei area changed from southeast to southwest in the middle late Miocene. Detrital apatite fission track and detrital zircon dating also indicate a sediment source change around $14 \mathrm{Ma}$ (Li JF et 

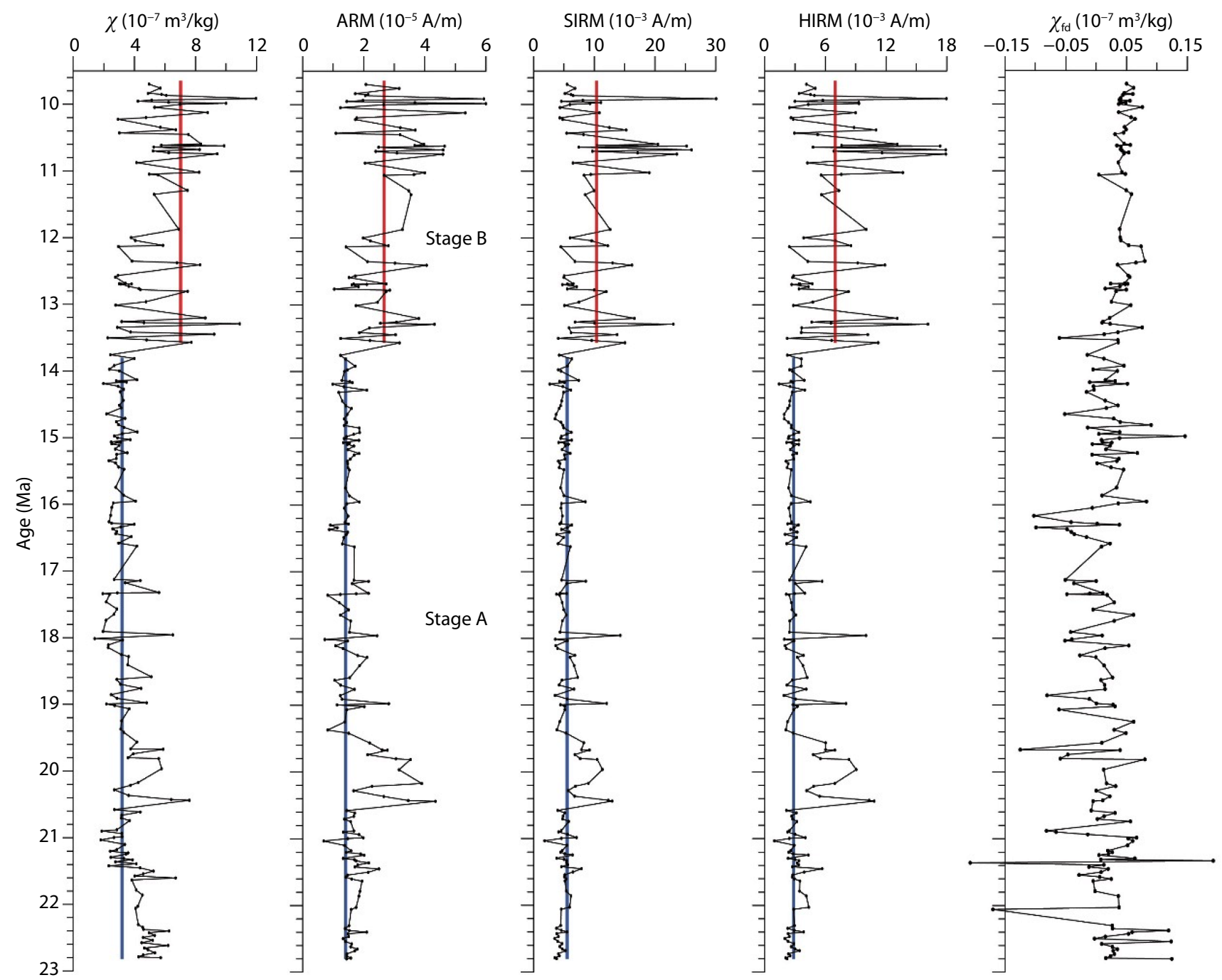

Figure 4. Comparison of magnetic susceptibility, anhysteretic remanent magnetization, saturation isothermal remanent magnetization, hard isothermal remanent magnetization and frequency-dependent susceptibility of the studied Tiejianggou Formation. The abrupt change at 13.7 Ma may represent the change of source materials.

al., 2014; Lin X et al., 2015). Based on sedimentary facies and sediment accumulation rate analysis, Sun JM et al. (2005) suggested that the source material changed at around 13.7 Ma, and that the main magnetic material changed from hematite to magnetite and hematite. We also suggest that the increase of susceptibility and magnetic remanences reflect the change of source materials.

Here is a possible scenario. The magnetite (source material) had undergone prolonged chemical weathering processes before it was transferred to the foreland basins by low energy rivers in stable tectonic periods; most of the minerals were preserved in the form of hematite. However, during periods of active tectonics, new bedrocks were uplifted and new minerals derived from the bedrocks were only partially oxidized because of intense erosion and high energy river floods. These resulted in the accumulation of molasse deposits in the foreland basins, with the minerals being a mixture of magnetite and hematite. It is worth noting that the HIRM results show that the absolute-concentration of hematite increased after 13.7 Ma. However, just as in the proposed scenario above, the absolute-concentration of magnetite also in- creased considerably, as evidenced by the sharp-increase of bulk magnetic susceptibility, due to the fact that the bulk susceptibility of magnetite is 1000 times greater than that of hematite (Collinson, 1983). Therefore, the relative-concentration of hematite, which is climate-dependent, did not increase after $13.7 \mathrm{Ma}$, a conclusion that can be further supported by the magnetic ratios and redness as indicated by Figures 5 and 6 . Conclusively, the activation of tectonics in the Subei area since $13.7 \mathrm{Ma}$ is the fundamental cause of the change of magnetic properties. This is in accordance with other reports concerning the uplift history of the northern Tibetan Plateau (Li JJ et al., 1997; Sun JM et al., 2005; Bovet et al., 2009; Li JF et al., 2014; Wang CS et al., 2014; Zhuang GS et al., 2014; Lin X et al., 2015; Lin XB et al., 2016; He PJ et al., 2018).

\subsection{MMCO During 17-14 Ma}

The interparametric ratios, IRM $100 \mathrm{mT} / \mathrm{IRM}_{30 \mathrm{mT}}, \mathrm{IRM}_{100 \mathrm{mT}} / \mathrm{IRM}_{60 \mathrm{mT}}$, and $\mathrm{IRM}_{100 \mathrm{mT}} / \mathrm{SIRM}$, can be used as indicators for the relative contributions of hematite (Deng CL et al., 2006). The $S$ ratio has been 

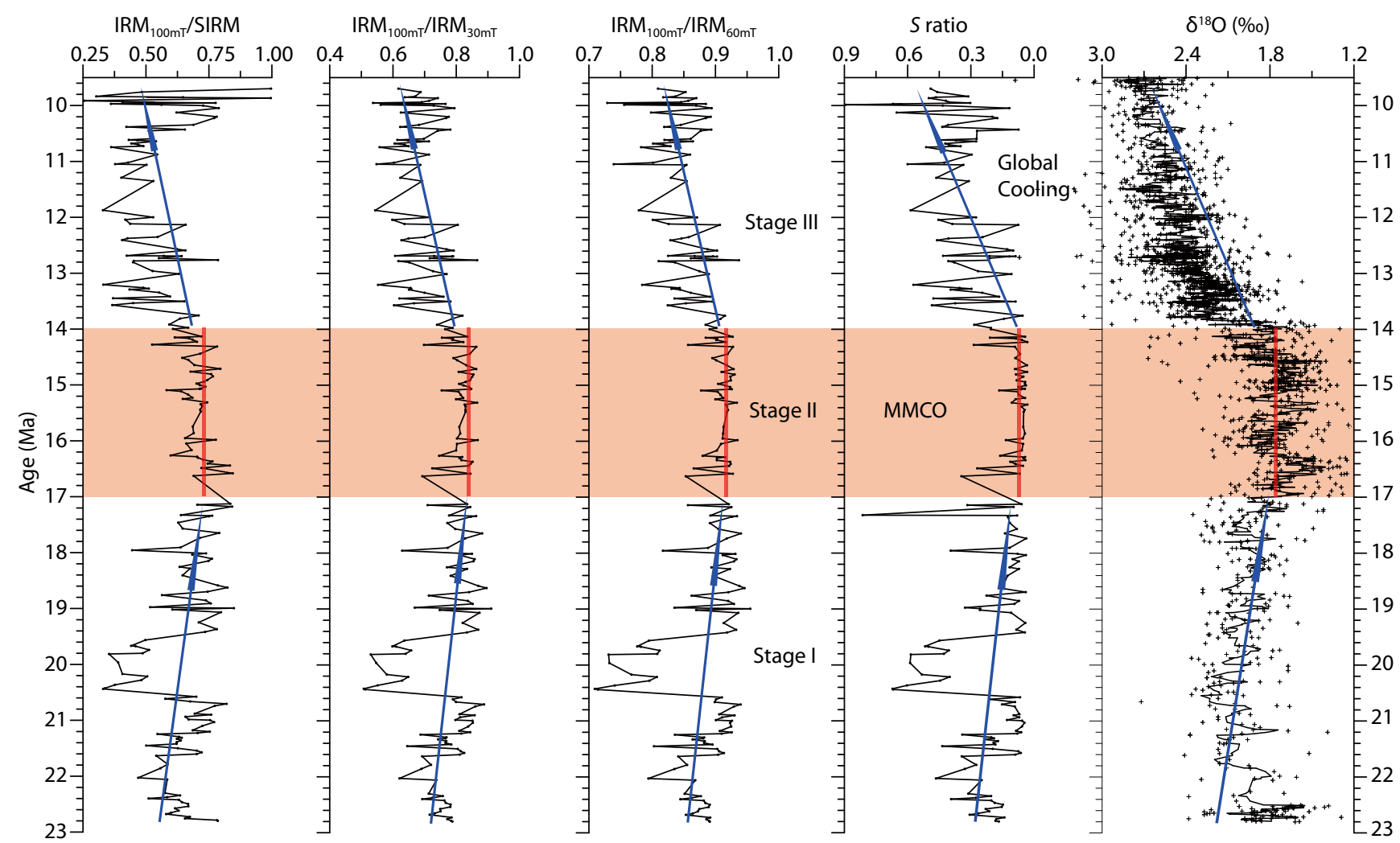

Figure 5. Comparison of IRM $100 \mathrm{mT} / \mathrm{IRM}_{30 \mathrm{mT}}, \mathrm{IRM}_{100 \mathrm{mT}} / \mathrm{IRM}_{60 \mathrm{mT}}, \mathrm{IRM}_{100 \mathrm{mT}} / \mathrm{SIRM}, \mathrm{S}$ ratio of the studied Tiejianggou Formation and the composite global marine oxygen isotope records. The oxygen isotope records are from Zachos et al. (2001). These ratios all show a good correlation. MMCO is identified from 17 to $14 \mathrm{Ma}$, followed by a global cooling trend.

widely used as a climatic proxy to measure the relative abundance of high-coercivity minerals in a mixture with ferrimagnetic minerals (e.g., magnetite, maghemite) (Yamazaki and loka, 1997; Rousse et al., 2006; Liu QS et al., 2007, 2012; Ao H et al., 2010; Fang XM et al., 2015; Zan JB et al., 2018; Guan C et al., 2019). Approaching unity points to the domination of ferrimagnetic minerals, and the $S$ ratio will decrease with an increase of hematite. Redness is an intuitive proxy to reflect the concentrations of iron-bearing components, mainly hematite, and is thus widely used (Nagao and Nakashima, 1992; Balsam et al., 1999; Helmke et al., 2002; Abdul Aziz et al., 2003; Aziz et al., 2004; Jiang HC et al., 2008; Sayem et al., 2018). Synthetically, these proxies suggest a maximal relative abundance of hematite from 17 to $14 \mathrm{Ma}$ and a decreasing trend of hematite concentration after $14 \mathrm{Ma}$.

As we have discussed above, tectonics had a profound influence on the abundance of hematite and magnetite. However, this tectonic influence can be eliminated by using the above ratios. In such a case, all these ratios reflect the relative-concentration of hematite to the total magnetic minerals rather than the absoluteconcentration of hematite or magnetite. This can be evidenced by the fact that all the magnetic ratios show a trend similar to that of the redness (Figures 5 and 6 ), which reflects mainly the climatecontrol degree of chemical weathering.

Consequently, the three stages we have identified from the magnetic ratios indicate different climate schemes. Stage I (22.8-17 $\mathrm{Ma}$ ): the ratios of $I R M_{100 \mathrm{mT}} / \mathrm{IRM}_{30 \mathrm{mT}}, \mathrm{IRM}_{100 \mathrm{mT}} / \mathrm{RM}_{60 \mathrm{mT}}$, and $\mathrm{IRM}_{100 \mathrm{mT}} / \mathrm{SIRM}$ all exhibit a generally increasing trend, whereas the $S$ ratio is generally decreasing (Figures 5); all these imply a trend towards a stronger chemical weathering process. Generally, Stage I is a temperate period compared with that of the MMCO. Stage II (17-14 Ma): the ratios of IRM $_{100 \mathrm{mT}} / \mathrm{IRM}_{30 \mathrm{mT}}$, IRM $\mathrm{IR}_{100 \mathrm{mT}} /$ $I M_{60 \mathrm{mT}}$, and IRM ${ }_{100 \mathrm{mT}} / \mathrm{SIRM}$ show their highest values while the $S$ ratio is at its minimum (Figure 5), indicating high values of the relative concentrations of hematite, thus the climate condition in this stage must be the warmest and the most humid of the Miocene. This warm phase corresponds to the MMCO (Miller et al., 1991; Wright et al., 1992; Flower and Kennett, 1994; Zachos et al., 2001; Sun JM and Zhang ZQ, 2008; Zan JB et al., 2015; Lin XB et al., 2016; Guan C et al., 2019). Stage III (14-9.7 Ma): decreasing ratios of IRM $100 \mathrm{mT} / \mathrm{IRM}_{30 \mathrm{mT}}, \mathrm{IRM}_{100 \mathrm{mT}} / \mathrm{IRM}_{60 \mathrm{mT}}$, and IRM $\mathrm{INOmT}_{10 \mathrm{~m}} / \mathrm{SIRM}$ and increasing values of the $S$ ratio are consistent with lower relativeconcentrations of hematite and thus suggestive of a weakening weathering process under a cooling climate.

\section{Conclusion}

Based on detailed analyses of the magnetic and color parameters of the Miocene strata in the Subei Basin, we can draw the following conclusion:

(1) The abrupt increase of bulk magnetic susceptibility, SIRM, ARM, and HIRM since 13.7 Ma mainly reflects the change of the absolute-concentration of magnetic minerals, which is related to changes in source materials in response to the intensive rock denudations related to tectonic uplift of the adjoining mountains since the late Miocene. 


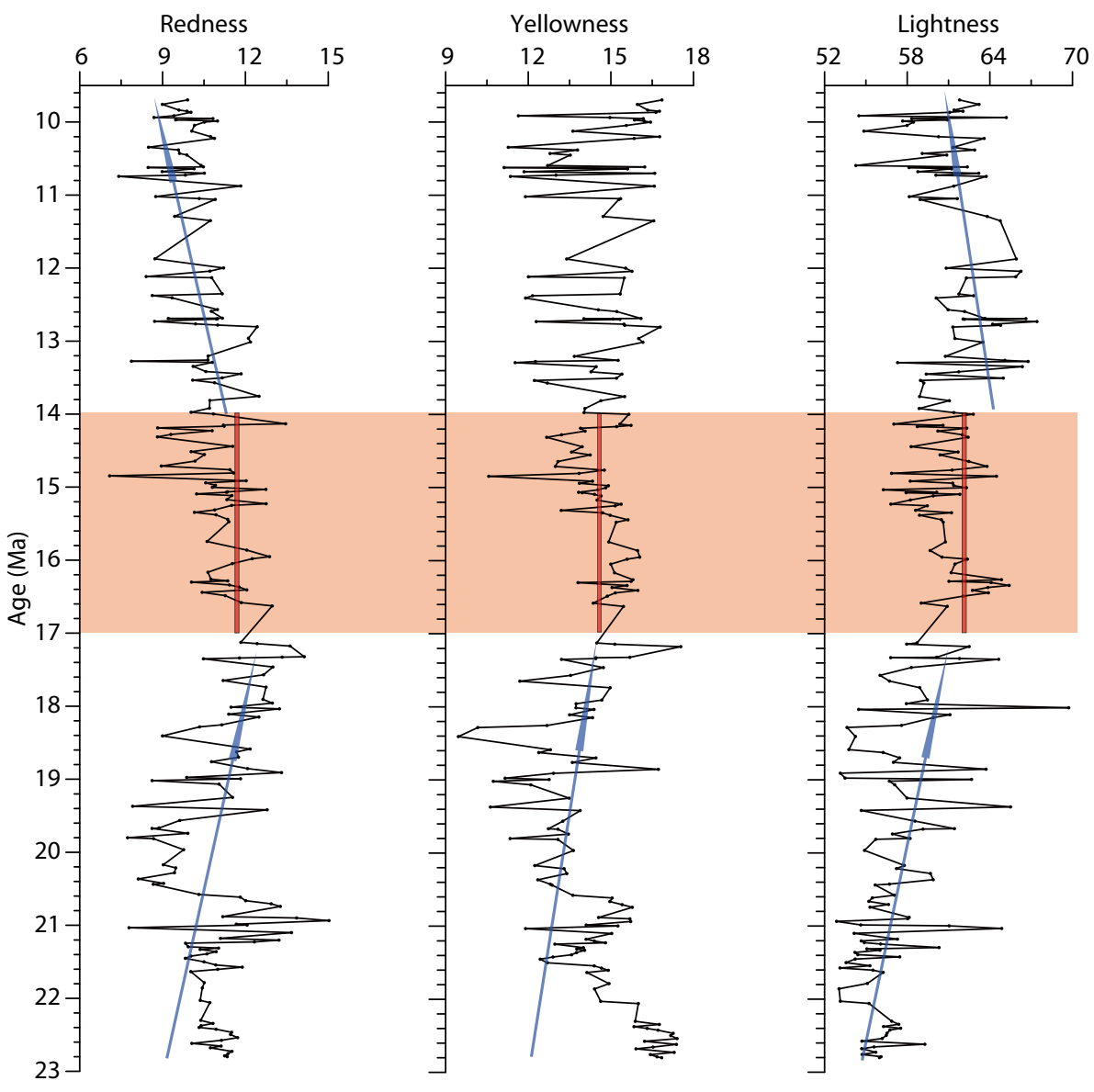

Figure 6. Plots of color records of the studied Tiejianggou Formation. The redness mainly reflects the abundance of hematite correlates well with $S$ ratio.

(2) Different from the bulk magnetic susceptibility, SIRM, ARM, and HIRM, the $S$ ratio, and the other ratios of $\mathrm{IRM}_{100 \mathrm{mT}} / \mathrm{SIRM}$, $\mathrm{IRM}_{100 \mathrm{mT}} / \mathrm{IRM}_{30 \mathrm{mT}}$, IRM $\mathrm{IROmT}_{100} / \mathrm{IRM}_{60 \mathrm{mT}}$, as well as the redness, all reflect changes in the relative-concentration of hematite, which were thus climate-dependent. The change pattern indicate three stepwise climatic changes: Stage I (22.8-17 Ma) is a temperate period with a slight warming trend; Stage II (17-14 Ma) is characterized by a warm phase corresponding to the MMCO; Stage III (14-9.7 Ma) reveals a weakening weathering process related to global cooling.

\section{Acknowledgments}

This study was supported financially by the National Nature Science Foundation of China (grants 41888101) and the Strategic Priority Research Program of the Chinese Academy of Sciences (XDA20070202). We thank the two anonymous reviewers for their constructive comments and suggestions.

\section{References}

Abdul Aziz, H., Krijgsman, W., Hilge ${ }^{\circ}$ Cn, F. J., Wilson, D. S., and Calvo, J. P. (2003). An astronomical polarity timescale for the late middle Miocene based on cyclic continental sequences. J. Geophy. Res.: Solid Earth, 108(B3), 2159. https://doi.org/10.1029/2002JB001818

Abreu, V. S., and Haddad, G. A. (1998). Glacioeustatic fluctuations: the mechanism linking stable isotope events and sequence stratigraphy from the Early Oligocene to Middle Miocene. In P. C. de Graciansky, et al. (Eds.), Mesozoic and Cenozoic Sequence Stratigraphy of European Basins. London: SEPM Society for Sedimentary Geology. https://doi.org/10.2110/pec.98.02.0245

An, Z. S., Kutzbach, J. E., Prell, W. L., and Porter, S. C. (2001). Evolution of Asian monsoons and phased uplift of the Himalaya-Tibetan plateau since Late Miocene times. Nature, 411(6833), 62-66. https://doi.org/10.1038/35075035

Ao, H., Deng, C. L., Dekkers, M. J., and Liu, Q. S. (2010). Magnetic mineral dissolution in Pleistocene fluvio-lacustrine sediments, Nihewan Basin (North China). Earth Planet. Sci. Lett., 292(1-2), 191-200. https://doi.org/10.1016/j.epsl.2010.01.035

Aziz, H. A., van Dam, J., Hilgen, F. J., and Krijgsman, W. (2004). Astronomical forcing in Upper Miocene continental sequences: implications for the Geomagnetic Polarity Time Scale. Earth Planet. Sci. Lett., 222(1), 243-258. https://doi.org/10.1016/j.epsl.2004.02.018

Balsam, W. L., Deaton, B. C., and Damuth, J. E. (1999). Evaluating optical lightness as a proxy for carbonate content in marine sediment cores. Mar. Geol., 161(2-4), 141-153. https://doi.org/10.1016/S0025-3227(99)00037-7

Bovet, P. M., Ritts, B. D., Gehrels, G., Abbink, A. O., Darby, B., and Hourigan, J. (2009). Evidence of Miocene crustal shortening in the north Qilian Shan from Cenozoic stratigraphy of the western Hexi Corridor, Gansu Province, China. Am. J. Sci., 309(4), 290-329. https://doi.org/10.2475/00.4009.02

Collinson, D. W. (1983). Methods in Rock Magnetism and Palaeomagnetism: Techniques and Instruments. London: Chapman \& Hall.

Deng, C. L., Vidic, N. J., Verosub, K. L., Singer, M. J., Liu, Q. S., Shaw, J., and Zhu, R. X. (2005). Mineral magnetic variation of the Jiaodao Chinese loess/paleosol sequence and its bearing on long-term climatic variability. J. Geophys. Res.: Solid Earth, 110(B3), B03103. https://doi.org/10.1029/2004JB003451

Deng, C. L., Shaw, J., Liu, Q. S., Pan, Y. X., and Zhu, R. X. (2006). Mineral magnetic 
variation of the Jingbian loess/paleosol sequence in the northern Loess Plateau of China: implications for Quaternary development of Asian aridification and cooling. Earth Planet. Sci. Lett., 241(1-2), 248-259. https://doi.org/10.1016/j.epsl.2005.10.020

Fang, X. M., Zan, J. B., Appel, E., Lu, Y., Song, C. H., Dai, S., and Tuo, S. B. (2015). An Eocene-Miocene continuous rock magnetic record from the sediments in the Xining Basin, NW China: indication for Cenozoic persistent drying driven by global cooling and Tibetan Plateau uplift. Geophys. J. Int., 201(1), 78-89. https://doi.org/10.1093/gji/ggv002

Flower, B. P., and Kennett, J. P. (1994). The middle Miocene climatic transition: East Antarctic ice sheet development, deep ocean circulation and global carbon cycling. Palaeogeogr., Palaeoclimatol., Palaeoecol., 108(3-4), 537-555. https://doi.org/10.1016/0031-0182(94)90251-8

Flower, B. P. (1999). Palaeoclimatology: Warming without high $\mathrm{CO}_{2}$ ?. Nature, 399(6734), 313-314. https://doi.org/10.1038/20568

Fu, C. F., Qiang, X. K., Xu, X. W., Xi, J. J., Zuo, J., and An, Z. S. (2018). Late Miocene magnetostratigraphy of Jianzha Basin in the northeastern margin of the Tibetan Plateau and changes in the East Asian summer monsoon. Geol. J., 53(S1), 282-292. https://doi.org/10.1002/gj.3047

Gilder, S., Chen, Y., and Sen, S. (2001). Oligo-Miocene magnetostratigraphy and rock magnetism of the Xishuigou section, Subei (Gansu Province, western China) and implications for shallow inclinations in central Asia. J. Geophys. Res. Solid Earth, 106(B12), 30505-30521. https://doi.org/10.1029/2001JB000325

Guan, C., Chang, H., Yan, M. D., Li, L. Y., Xia, M. M., Zan, J. B., and Liu, S. C. (2019). Rock magnetic constraints for the Mid-Miocene Climatic Optimum from a high-resolution sedimentary sequence of the northwestern Qaidam Basin, NE Tibetan Plateau. Palaeogeogr., Palaeoclimatol., Palaeoecol., 532, 109263. https://doi.org/10.1016/j.palaeo.2019.109263

Guo, Z. T., Ruddiman, W. F., Hao, Q. Z., Wu, H. B., Qiao, Y. S., Zhu, R. X., Peng, S. Z., Wei, J. J., Yuan, B. Y., and Liu, T. S. (2002). Onset of Asian desertification by 22 Myr ago inferred from loess deposits in China. Nature, 416(6877), 159-163. https://doi.org/10.1038/416159a

Hao, Q. Z., Oldfield, F., Bloemendal, J., and Guo, Z. T. (2008). The magnetic properties of loess and paleosol samples from the Chinese Loess Plateau spanning the last 22 million years. Palaeogeogr., Palaeoclimatol., Palaeoecol., 260(3-4), 389-404. https://doi.org/10.1016/j.palaeo.2007.11.010

He, P. J., Song, C. H., Wang, Y. D., Meng, Q. Q., Chen, L. H., Yao, L. J., Huang, R. H., Feng, W., and Chen, S. (2018). Cenozoic deformation history of the Qilian Shan (northeastern Tibetan Plateau) constrained by detrital apatite fissiontrack thermochronology in the northeastern Qaidam Basin. Tectonophysics, 749, 1-11. https://doi.org/10.1016/j.tecto.2018.10.017

Heller, F., and Tungsheng, L. (1984). Magnetism of Chinese loess deposits. Geophysical Journal International, 77(1), 125-141. https://doi.org/10.1111/j.1365-246X.1984.tb01928.x

Helmke, J. P., Schulz, M., and Bauch, H. A. (2002). Sediment-color record from the Northeast Atlantic Reveals patterns of millennial-Scale Climate variability during the Past 500, 000 years. Quat. Res., 57(1), 49-57. https://doi.org/10.1006/qres.2001.2289

Holbourn, A., Kuhnt, W., Lyle, M., Schneider, L., Romero, O., and Andersen, N. (2014). Middle Miocene climate cooling linked to intensification of eastern equatorial Pacific upwelling. Geology, 42(1), 19-22. https://doi.org/10.1130/G34890.1

Hui, Z. C., Zhang, J., Ma, Z. H., Li, X. M., Peng, T. J., Li, J. J., and Wang, B. (2018). Global warming and rainfall: Lessons from an analysis of Mid-Miocene climate data. Palaeogeogr., Palaeoclimatol., Palaeoecol., 512, 106-117. https://doi.org/10.1016/j.palaeo.2018.10.025

Jiang, H. C., Ji, J. L., Gao, L., Tang, Z. H., and Ding, Z. L. (2008). Cooling-driven climate change at 12-11 Ma: Multiproxy records from a long fluviolacustrine sequence at Guyuan, Ningxia, China. Palaeogeogr., Palaeoclimatol., Palaeoecol., 265(1-2), 148-158. https://doi.org/10.1016/j.palaeo.2008.05.006

Larsson, L. M., Dybkjær, K., Rasmussen, E. S., Piasecki, S., Utescher, T., and Vajda, V. (2011). Miocene climate evolution of northern Europe: A palynological investigation from Denmark. Palaeogeogr., Palaeoclimatol., Palaeoecol., 309(3-4), 161-175. https://doi.org/10.1016/j.palaeo.2011.05.003
Li, J. F., Zhang, Z. C., Tang, W. H., Li, K., Luo, Z. W., and Li, J. (2014). Provenance of Oligocene-Miocene sediments in the Subei area, eastern Altyn Tagh fault and its geological implications: Evidence from detrital zircons LA-ICP-MS U-Pb chronology. J. Asian Earth Sci., 87, 130-140. https://doi.org/10.1016/j.jseaes.2014.02.015

Li, J. J., Fang, X. M., Van der Voo, R., Zhu, J. J., Mac Niocaill, C., Cao, J. X., Zhong, W., Chen, H. L., Wang, J. L., ... Zhang, Y. C. (1997). Late Cenozoic magnetostratigraphy (11-0 Ma) of the Dongshanding and Wangjiashan sections in the Longzhong Basin, western China. Geol. Mijnbouw, 76(1-2), 121-134. https://doi.org/10.1023/A:1003153717799

Lin, X., Zheng, D. W., Sun, J. M., Windley, B. F., Tian, Z. H., Gong, Z. J., and Jia, Y. Y. (2015). Detrital apatite fission track evidence for provenance change in the Subei Basin and implications for the tectonic uplift of the Danghe Nan Shan (NW China) since the mid-Miocene. J. Asian Earth Sci., 111, 302-311. https://doi.org/10.1016/j.jseaes.2015.07.007

Lin, X. B., Wyrwoll, K. H., Chen, H. L., and Cheng, X. G. (2016). On the timing and forcing mechanism of a mid-Miocene arid climate transition at the NE margins of the Tibetan Plateau: stratigraphic and sedimentologic evidence from the Sikouzi Section. Int. J. Earth Sci., 105(3), 1039-1049. https://doi.org/10.1007/s00531-015-1213-z

Liu, Q. S., Deng, C. L., Torrent, J., and Zhu, R. X. (2007). Review of recent developments in mineral magnetism of the Chinese loess. Quat. Sci. Rev., 26(3-4), 368-385. https://doi.org/10.1016/j.quascirev.2006.08.004

Liu, Q. S., Roberts, A. P., Larrasoana, J. C., Banerjee, S. K., Guyodo, Y., Tauxe, L., and Oldfield, F. (2012). Environmental magnetism: principles and applications. Rev. Geophys., 50(4), RG4002. https://doi.org/10.1029/2012RG000393

Miao, Y. F., Fang, X. M., Herrmann, M., Wu, F. L., Zhang, Y. Z., and Liu, D. L. (2011). Miocene pollen record of KC-1 core in the Qaidam Basin, NE Tibetan Plateau and implications for evolution of the East Asian monsoon. Palaeogeogr., Palaeoclimatol., Palaeoecol., 299(1-2), 30-38. https://doi.org/10.1016/j.palaeo.2010.10.026

Miao, Y. F., Herrmann, M., Wu, F. L., Yan, X. L., and Yang, S. L. (2012). What controlled Mid-Late Miocene long-term aridification in Central Asia?-Global cooling or Tibetan Plateau uplift: A review. Earth-Sci. Rev., 112(3-4), 155-172. https://doi.org/10.1016/j.earscirev.2012.02.003

Miller, K. G., Wright, J. D., and Fairbanks, R. G. (1991). Unlocking the ice house: Oligocene-Miocene oxygen isotopes, eustasy, and margin erosion. J. Geophys. Res.: Solid Earth, 96(B4), 6829-6848. https://doi.org/10.1029/90JB02015

Molnar, P., England, P., and Martinod, J. (1993). Mantle dynamics, uplift of the Tibetan Plateau, and the Indian Monsoon. Rev. Geophys., 31(4), 357-396. https://doi.org/10.1029/93RG02030

Nagao, S., and Nakashima, S. (1992). The factors controlling vertical color variations of North Atlantic Madeira Abyssal Plain sediments. Mar. Geol., 109(1-2), 83-94. https://doi.org/10.1016/0025-3227(92)90222-4

Raymo, M. E., and Ruddiman, W. F. (1992). Tectonic forcing of late Cenozoic climate. Nature, 359(6391), 117-122. https://doi.org/10.1038/359117a0

Ritts, B. D., Yue, Y. J., and Graham, S. A. (2004). Oligocene-Miocene tectonics and sedimentation along the Altyn Tagh fault, northern Tibetan Plateau: Analysis of the Xorkol, Subei, and Aksay basins. J. Geol., 112(2), 207-229. https://doi.org/10.1086/381658

Rousse, S., Kissel, C., Laj, C., Eiríksson, J., and Knudsen, K. L. (2006). Holocene centennial to millennial-scale climatic variability: Evidence from highresolution magnetic analyses of the last 10 cal kyr off North Iceland (core MD99-2275). Earth Planet. Sci. Lett., 242(3-4), 390-405. https://doi.org/10.1016/j.epsl.2005.07.030

Sayem, A. S. M., Guo, Z. T., Wu, H. B., Zhang, C. X., Yang, F., Xiao, G. Q., and He, Z. L. (2018). Sedimentary and geochemical evidence of Eocene climate change in the Xining Basin, northeastern Tibetan Plateau. Sci. China Earth Sci., 61(9), 1292-1305. https://doi.org/10.1007/s11430-018-9231-9

Song, C. H., Hu, S. H., Han, W. X., Zhang, T., Fang, X. M., Gao, J. P., and Wu, F. L. (2014). Middle Miocene to earliest Pliocene sedimentological and geochemical records of climate change in the western Qaidam Basin on the NE Tibetan Plateau. Palaeogeogr., Palaeoclimatol., Palaeoecol., 395, 67-76. https://doi.org/10.1016/j.palaeo.2013.12.022 
Song, Y. G., Wang, Q. S., An, Z. S., Qiang, X. K., Dong, J. B., Chang, H., Zhang, M. S., and Guo, X. H. (2018). Mid-Miocene climatic optimum: Clay mineral evidence from the red clay succession, Longzhong Basin, Northern China. Palaeogeogr., Palaeoclimatol., Palaeoecol.,, 46-55. https://doi.org/10.1016/j.palaeo.2017.10.001

Sun, J. M., and Liu, T. S. (2000). Multiple origins and interpretations of the magnetic susceptibility signal in Chinese wind-blown sediments. Earth Planet. Sci. Lett., 180(3-4), 287-296. https://doi.org/10.1016/S0012821X(00)00175-8

Sun, J. M., Liu, T. S., and An, Z. S. (2005). Tectonic uplift in the northern Tibetan Plateau since 13.7 Ma ago inferred from molasse deposits along the Altyn Tagh Fault. Earth Planet. Sci. Lett., 235(3-4), 641-653. https://doi.org/10.1016/j.epsl.2005.04.034

Sun, J. M., and Zhang, Z. Q. (2008). Palynological evidence for the Mid-Miocene Climatic Optimum recorded in Cenozoic sediments of the Tian Shan Range, northwestern China. Global Planet. Change, 64(1-2), 53-68. https://doi.org/10.1016/j.gloplacha.2008.09.001

Turco, E., Hilgen, F. J., Lourens, L. J., Shackleton, N. J., and Zachariasse, W. J. (2001). Punctuated evolution of global climate cooling during the Late Middle to Early Late Miocene: High-resolution planktonic foraminiferal and oxygen isotope records from the Mediterranean. Paleoceanography, 16(4), 405-423. https://doi.org/10.1029/2000PA000509

Van der Woerd, J., Xu, X. W., Li, H. B., Tapponnier, P., Meyer, B., Ryerson, F. J., Meriaux, A. S., and Xu, Z. Q. (2001). Rapid active thrusting along the northwestern range front of the Tanghe Nan Shan (western Gansu, China). J. Geophys. Res. Solid Earth, 106(B12), 30475-30504. https://doi.org/10.1029/2001JB000583

Verosub, K. L., Fine, P., Singer, M. J., and TenPas, J. (1993). Pedogenesis and paleoclimate: Interpretation of the magnetic susceptibility record of Chinese loess-paleosol sequences. Geology, 21(11), 1011-1014. https://doi.org/10.1130/0091-7613(1993)021<1011:PAPIOT>2.3.CO;2

Wan, S. M., Kürschner, W. M., Clift, P. D., Li, A. C., and Li, T. G. (2009). Extreme weathering/erosion during the Miocene Climatic Optimum: evidence from sediment record in the South China Sea. Geophys. Res. Lett., 36(19), L19706. https://doi.org/10.1029/2009GL040279

Wang, C. S., Dai, J. G., Zhao, X. X., Li, Y. L., Graham, S. A., He, D. F., Ran, B., and Meng, J. (2014). Outward-growth of the Tibetan Plateau during the Cenozoic: A review. Tectonophysics, 621, 1-43. https://doi.org/10.1016/j.tecto.2014.01.036

Wang, X. M., Wang, B. Y., Qiu, Z. X., Xie, G. P., Xie, J. Y., Downs, W., Qiu, Z. D., and Deng, T. (2003). Danghe area (western Gansu, China) biostratigraphy and implications for depositional history and tectonics of northern Tibetan Plateau. Earth Planet. Sci. Lett., 208(3-4), 253-269. https://doi.org/10.1016/S0012-821X(03)00047-5

Wright, J. D., Miller, K. G., and Fairbanks, R. G. (1992). Early and middle Miocene stable isotopes: implications for deepwater circulation and climate. Paleoceanography, 7(3), 357-389. https://doi.org/10.1029/92PA00760

Yamazaki, T., and loka, N. (1997). Environmental rock-magnetism of pelagic clay: Implications for Asian eolian input to the North Pacific since the Pliocene. Paleoceanography, 12(1), 111-124. https://doi.org/10.1029/96PA02757

Yin, A., Rumelhart, P. E., Butler, R., Cowgill, E., Harrison, T. M., Foster, D. A., Ingersoll, R. V., Zhang, Q., Zhou, X. Q., ... Raza, A. (2002). Tectonic history of the Altyn Tagh fault system in northern Tibet inferred from Cenozoic sedimentation. GSA Bull., 114(10), 1257-1295. https://doi.org/10.1130/00167606(2002)114<1257:THOTAT>2.0.CO;2

Zachos, J., Pagani, M., Sloan, L., Thomas, E., and Billups, K. (2001). Trends, rhythms, and aberrations in global climate $65 \mathrm{Ma}$ to present. Science, 292(5517), 686-693. https://doi.org/10.1126/science.1059412

Zachos, J. C., Dickens, G. R., and Zeebe, R. E. (2008). An early Cenozoic perspective on greenhouse warming and carbon-cycle dynamics. Nature, 451(7176), 279-283. https://doi.org/10.1038/nature06588

Zan, J. B., Fang, X. M., Yan, M. D., Zhang, W. L., and Lu, Y. (2015). Lithologic and rock magnetic evidence for the Mid-Miocene Climatic Optimum recorded in the sedimentary archive of the Xining Basin, NE Tibetan Plateau.

Palaeogeogr., Palaeoclimatol., Palaeoecol., 431, 6-14.

https://doi.org/10.1016/j.palaeo.2015.04.024

Zan, J. B., Kang, J., Yan, M. D., Fang, X. M., Li, X. J., Guan, C., Zhang, W. L., and Fang, Y. H. (2018). A pedogenic model for the magnetic enhancement of late miocene fluvial-lacustrine sediments from the Xining Basin, NE Tibetan Plateau. J. Geophys. Res. Solid Earth, 123(8), 6176-6194. https://doi.org/10.1029/2018JB016064

Zhang, T., Han, W. X., Fang, X. M., Zhang, W. L., Song, C. H., and Yan, M. D. (2016). Intensified tectonic deformation and uplift of the Altyn Tagh range recorded by rock magnetism and growth strata studies of the western Qaidam Basin, NE Tibetan Plateau. Global Planet. Change, 137, 54-68. https://doi.org/10.1016/j.gloplacha.2015.12.017

Zhou, L. P., Oldfield, F., Wintle, A. G., Robinson, S. G., and Wang, J. T. (1990). Partly pedogenic origin of magnetic variations in Chinese loess. Nature, 346(6286), 737-739. https://doi.org/10.1038/346737a0

Zhuang, G. S., Hourigan, J. K., Ritts, B. D., and Kent-Corson, M. L. (2011). Cenozoic multiple-phase tectonic evolution of the Northern Tibetan Plateau: Constraints from sedimentary records from Qaidam Basin, Hexi Corridor, and Subei Basin, Northwest China. Am. J. Sci., 311(2), 116-152. https://doi.org/10.2475/02.2011.02

Zhuang, G. S., Brandon, M. T., Pagani, M., and Krishnan, S. (2014). Leaf wax stable isotopes from Northern Tibetan Plateau: Implications for uplift and climate since 15 Ma. Earth Planet. Sci. Lett., 390, 186-198. https://doi.org/10.1016/j.epsl.2014.01.003 